\title{
Complete genome sequence of Kosakonia oryzae type strain Ola $51^{\top}$
}

Yuanyuan $\mathrm{Li}^{1 \dagger}$, Shuying $\mathrm{Li}^{1 \dagger}$, Mingyue Chen', Guixiang Peng ${ }^{2}$, Zhiyuan $\operatorname{Tan}^{3^{*}}$ and Qianli $\mathrm{An}^{1^{*}}$ (D)

\begin{abstract}
Strain Ola $51^{\top}$ (=LMG $24251^{\top}=$ CGMCC $\left.1.7012^{\top}\right)$ is the type strain of the species Kosakonia oryzae and was isolated from surface-sterilized roots of the wild rice species Oryza latifolia grown in Guangdong, China. Here we summarize the features of the strain Ola $51^{\top}$ and describe its complete genome sequence. The genome contains one circular chromosome of 5,303,342 nucleotides with 54.01\% GC content, 4773 protein-coding genes, 16 rRNA genes, 76 tRNA genes, 13 ncRNA genes, 48 pseudo genes, and 1 CRISPR array.
\end{abstract}

Keywords: Endophyte, Kosakonia, Nitrogen fixation, Plant growth-promoting bacteria

\section{Introduction}

Enterobacter cowanii [1], E. radicincitans [2], E. oryzae [3], E. arachidis [4], E. sacchari [5], E. oryziphilus [6, 7], and E. oryzendophyticus $[6,7]$ have been transferred into the novel genus Kosakonia of the family "Enterobacteriaceae" [8-10]. A novel species "Kosakonia pseudosacchari" [11] closely related to K. sacchari was recently proposed. With the exception of the type species K. cowanii, which was originally obtained from clinical samples [1], the other members of the genus Kosakonia are nitrogen-fixing bacteria associated with plants $[2-6,11]$ and commonly occur in the nitrogen-fixing bacterial community of some non-legume crops, such as rice [6] and sugarcane [12]. Some nitrogen-fixing Kosakonia strains are able to promote crop growth [12-14].

Strain Ola $51^{\mathrm{T}}\left(=\mathrm{LMG} 24251^{\mathrm{T}}=\right.$ CGMCC $\left.1.7012^{\mathrm{T}}\right)$ is the type strain of the species Kosakonia oryzae and was isolated from surface-sterilized roots of the wild rice species Oryza latifolia grown in Guangdong, China [3]. Here we present the summary of the features of the $K$. oryzae type strain Ola $51^{\mathrm{T}}$ and its complete genome sequence, which provides a reference for resolving the phylogeny and taxonomy of closely related strains and

\footnotetext{
* Correspondence: zytan@scau.edu.cn; an@zju.edu.cn

† Equal contributors

${ }^{3}$ College of Agriculture, South China Agricultural University, Guangzhou 510642 , China

${ }^{1}$ State Key Laboratory of Rice Biology, Institute of Biotechnology, Zhejiang University, Hangzhou, China

Full list of author information is available at the end of the article
}

the genetic information to study its plant growthpromoting potential and its plant-associated life style.

\section{Organism information Classification and features}

K. oryzae strain Ola $51^{\mathrm{T}}$ is a Gram-negative, non-sporeforming, motile rod with peritrichous flagella (Fig. 1). It grows aerobically but reduces $\mathrm{N}_{2}$ to $\mathrm{NH}_{3}$ at a low $\mathrm{pO}_{2}$. It forms circular, convex, smooth colonies with entire margins on nutrient agar [3, 8]. It grows best around $30{ }^{\circ} \mathrm{C}$ and pH 7 (Table 1) [3]. K. oryzae Ola $51^{\mathrm{T}}$ has the typical biochemical phenotypes of the genus Kosakonia: positive for acetoin production (Voges-Proskauer test) while negative for indole production; positive for $\beta$ galactosidase and arginine dihydrolase while negative for lysine decarboxylase; positive for oxidation of arabinose, cellobiose, citrate, fructose, galactose, gluconate, glucose, glycerol, lactose, malate, maltose, mannitol, mannose, sorbitol, sucrose and trehalose (Table 1) [3, 8].

The 16S rRNA gene sequence of $K$. oryzae Ola $51^{\mathrm{T}}$ was deposited in GenBank under the accession number EF488759 [3]. A phylogenetic analysis of the 16S rRNA gene sequences from the strains belonging to the genus Kosakonia and Escherichia coli ATCC11775 ${ }^{\mathrm{T}}$ (the type strain of the type species of the type genus of the family Enterobacteriaceae) showed that $K$. oryzae Ola $51^{\mathrm{T}}$ is most closely related to the strains belonging to the species $K$. radicincitans (Fig. 2) [3, 8-11]. 


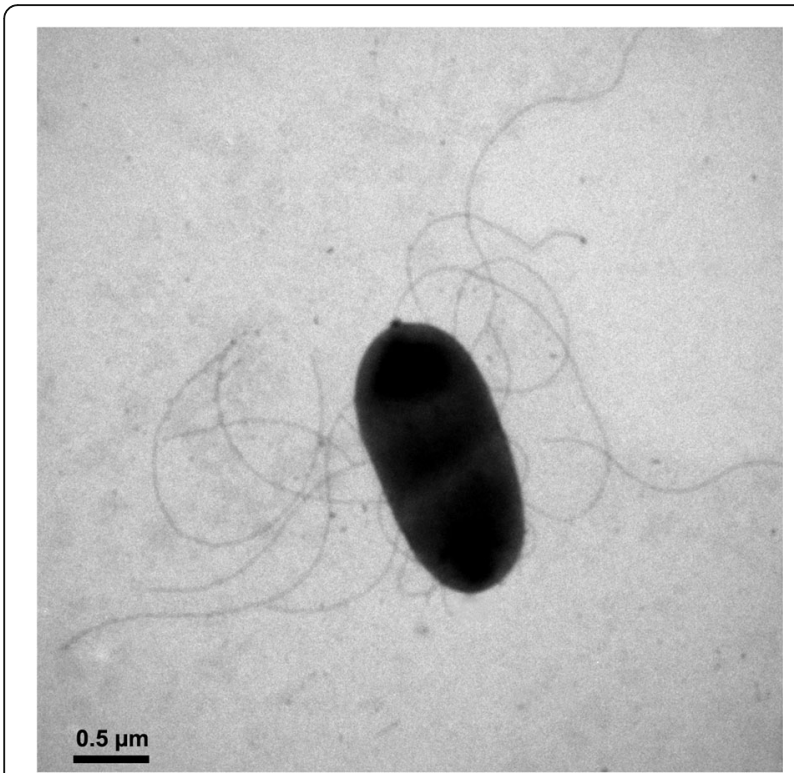

Fig. 1 Cell morphology of the Kosakonia oryzae type strain Ola $51^{\top}$. The bacterium was stained by uranyl acetate and observed by a transmission electron microscope

\section{Chemotaxonomic data}

Whole-cell fatty acids were extracted from cells grown aerobically at $28{ }^{\circ} \mathrm{C}$ for $24 \mathrm{~h}$ on the TSA medium according to the recommendations of the Microbial Identification System (MIDI Inc., Delaware USA). The whole-cell fatty acid composition was determined using a $6890 \mathrm{~N}$ gas chromatograph (Agilent Technologies, Santa Clara, USA) and the peaks of the profiles were identified using the TSBA50 identification library version 5.0 (MIDI). K. oryzae Ola $51^{\mathrm{T}}$ shows the typical cell fatty acid profile of the genus Kosakonia [8]. The major fatty acids are $\mathrm{C}_{16: 0}, \mathrm{C}_{18: 1 \omega 7 \mathrm{c}}, \mathrm{C}_{16: 1 \omega 7 \mathrm{c} / 15: 0 \text { iso } 2 \mathrm{OH}}, \mathrm{C}_{17: 0 \text { cyclo }}$ and $\mathrm{C}_{14: 0} 3 \mathrm{OH} / 16: 1$ iso I $[8,11]$.

\section{Genome sequencing information}

Genome project history

K. oryzae Ola $51^{\mathrm{T}}$ was selected for sequencing based on its taxonomic significance. The genome sequence is deposited in GenBank under the accession number CP014007. A summary of the genome sequencing project information and its association with MIGS version 2.0 [15] is shown in Table 2.

\section{Growth conditions and genomic DNA preparation}

K. oryzae Ola $51^{\mathrm{T}}$ was grown aerobically in liquid LuriaBertani medium at $30{ }^{\circ} \mathrm{C}$ until early stationary phase. The genome DNA was extracted from the cells by using a TIANamp bacterial DNA kit (Tiangen Biotech, Beijing, China). DNA quality (OD260/OD280 $=1.8)$ and quantity $(22 \mu \mathrm{g})$ were determined with a Nanodrop spectrometer (Thermo Scientific, Wilmington, USA).
Table 1 Classification and general features of Kosakonia oryzae strain Ola $51^{\top}$ according to the MIGS recommendations [15]

\begin{tabular}{|c|c|c|c|}
\hline MIGS ID & Property & Term & $\begin{array}{l}\text { Evidence } \\
\text { code }^{\mathrm{a}}\end{array}$ \\
\hline & \multirow[t]{8}{*}{ Classification } & Domain Bacteria & TAS [34] \\
\hline & & Phylum Proteobacteria & TAS [35] \\
\hline & & Class Gammaproteobacteria & $\operatorname{TAS}[36,37]$ \\
\hline & & Order "Enterobacteriales" & TAS [38] \\
\hline & & Family Enterobacteriaceae & $\operatorname{TAS}[39,40]$ \\
\hline & & Genus Kosakonia & TAS [8] \\
\hline & & Species Kosakonia oryzae & $\operatorname{TAS}[3,8]$ \\
\hline & & Type strain: Ola $51^{\top}$ & TAS [3] \\
\hline & Gram stain & Negative & TAS [3] \\
\hline & Cell shape & Rod & TAS [3] \\
\hline & Motility & Motile & TAS [3] \\
\hline & Sporulation & Non-sporulating & TAS [3] \\
\hline & $\begin{array}{l}\text { Temperature } \\
\text { range }\end{array}$ & $10-40{ }^{\circ} \mathrm{C}$ & TAS [3] \\
\hline & $\begin{array}{l}\text { Optimum } \\
\text { temperature }\end{array}$ & $28-37^{\circ} \mathrm{C}$ & TAS [3] \\
\hline & \multirow{2}{*}{$\begin{array}{l}\mathrm{pH} \text { range; } \\
\text { Optimum } \\
\text { Carbon source }\end{array}$} & \multirow{2}{*}{$\begin{array}{l}\text { 3.5-10; } 6.0-8.0 \\
\text { Arabinose, cellobiose, } \\
\text { citrate, fructose, galactose, } \\
\text { gluconate, glucose, glycerol, } \\
\text { lactose, malate, maltose, } \\
\text { mannitol, mannose, sorbitol, } \\
\text { sucrose \& trehalose }\end{array}$} & TAS [3] \\
\hline & & & $\operatorname{TAS}[3,8]$ \\
\hline MIGS-6 & Habitat & Plants & TAS [3] \\
\hline MIGS-6.3 & Salinity & $0-5 \% \mathrm{NaCl}(\mathrm{w} / \mathrm{v})$ & TAS [3] \\
\hline MIGS-22 & $\begin{array}{l}\text { Oxygen } \\
\text { requirement }\end{array}$ & Facultatively anaerobic & TAS [3] \\
\hline MIGS-15 & $\begin{array}{l}\text { Biotic } \\
\text { relationship }\end{array}$ & Free-living, endophytic & TAS [3] \\
\hline MIGS-14 & Pathogenicity & Not reported & \\
\hline MIGS-4 & $\begin{array}{l}\text { Geographic } \\
\text { location }\end{array}$ & $\begin{array}{l}\text { Guangzhou, Guangdong, } \\
\text { China }\end{array}$ & TAS [3] \\
\hline MIGS-5 & $\begin{array}{l}\text { Sample } \\
\text { collection }\end{array}$ & September 12, 2005 & TAS [3] \\
\hline \multirow{2}{*}{$\begin{array}{l}\text { MIGS-4.1 } \\
\text { MIGS-4.2 }\end{array}$} & Latitude & $23.1634171311^{\circ} \mathrm{N}$ & NAS \\
\hline & Longitude & $113.3534469581^{\circ} \mathrm{E}$ & NAS \\
\hline MIGS-4.3 & Depth & $\begin{array}{l}0.2-0.3 \mathrm{~m} \text { below the } \\
\text { surface }\end{array}$ & TAS [3] \\
\hline MIGS-4.4 & Altitude & $20 \mathrm{~m}$ & NAS \\
\hline
\end{tabular}

${ }^{a}$ Evidence codes - IDA: Inferred from Direct Assay; TAS: Traceable Author Statement (i.e., a direct report exists in the literature); NAS: Non-traceable Author Statement (i.e., not directly observed for the living, isolated sample, but based on a generally accepted property for the species, or anecdotal evidence). These evidence codes are from the Gene Ontology project [41]

\section{Genome sequencing and assembly}

The genomic DNA of $K$. oryzae Ola $51^{\mathrm{T}}$ was constructed into $8-11 \mathrm{~kb}$ insert libraries and sequenced using PacBio SMRT sequencing technology [16] at the Duke University Genome Sequencing \& Analysis Core 


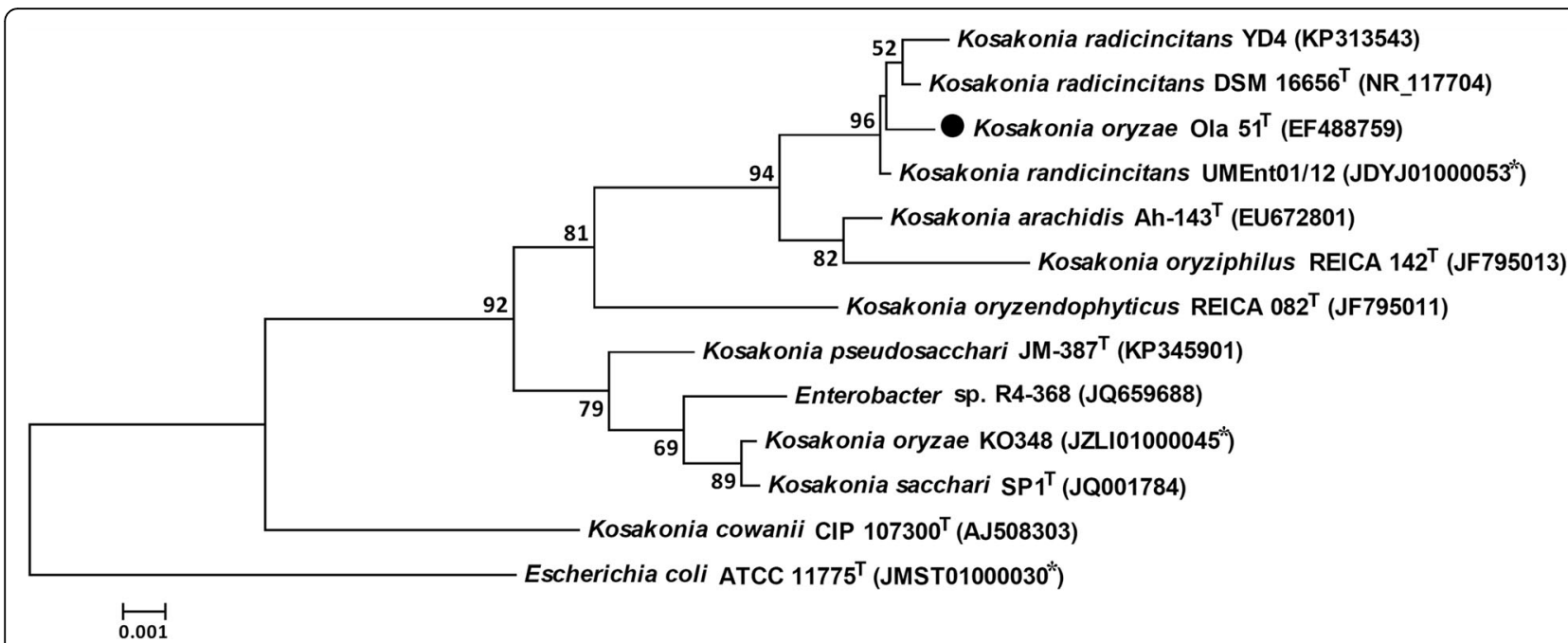

Fig. 2 Phylogenetic tree based on the 16S rRNA gene sequences showing the phylogenetic position of the Kosakonia oryzae type strain Ola $51^{\top}$ $(\bullet)$ and other strains belonging to the genus Kosakonia. The sequences were aligned using the SINA (SILVA Incremental Aligner) Alignment Service [42] and were constructed to the phylogenetic tree with the neighbor-joining algorithm and the Kimura 2-parameter model integrated in the MEGA 5.2 program [43]. Bootstrap values (>50\%) of 1,000 tests are shown at the nodes. The tree was rooted on the outgroup Escherichia coli ATCC $11775^{\top}$. The GenBank accession numbers of the sequences are indicated in brackets; ${ }^{*}$ indicates the accession number of a contig of the whole genome sequence. The scale bar indicates $0.1 \%$ substitutions per site

Resource. Sequencing was run on two SMRT cells and resulted in 124,997 high-quality filtered reads with an average length of $8,260 \mathrm{bp}$. High-quality reads were assembled by the RS_HGAP_Assembly. 3 in the SMRT analysis v2.3.0. The final assembly produced 128 -fold coverage of the genome.

Table 2 Genome sequencing project information for Kosakonia oryzae strain Ola $51^{\top}$

\begin{tabular}{|c|c|c|}
\hline MIGS ID & Property & Term \\
\hline MIGS 31 & Finishing quality & Finished \\
\hline MIGS-28 & Libraries used & PacBio 8 -11 Kb library \\
\hline MIGS 29 & Sequencing platforms & PacBio RS ॥ \\
\hline $\begin{array}{l}\text { MIGS } \\
31.2\end{array}$ & Fold coverage & PacBio $128 \times$ \\
\hline MIGS 30 & Assemblers & $\begin{array}{l}\text { HGAP Assembly.3 in SMRT analysis- } \\
\text { 2.3.0 }\end{array}$ \\
\hline \multirow[t]{6}{*}{ MIGS 32} & Gene calling method & GeneMarkS+ \\
\hline & Locus Tag & AWR26 \\
\hline & Genbank ID & СР014007 \\
\hline & $\begin{array}{l}\text { GenBank Date of } \\
\text { Release }\end{array}$ & June 6, 2016 \\
\hline & GOLD ID & Gp0154734 \\
\hline & BIOPROJECT & PRJNA309028 \\
\hline \multirow[t]{2}{*}{ MIGS 13} & $\begin{array}{l}\text { Source Material } \\
\text { Identifier }\end{array}$ & LMG $24251^{\top}=$ CGMCC $1.7012^{\top}$ \\
\hline & Project relevance & $\begin{array}{l}\text { Taxonomy, agriculture, plant-microbe } \\
\text { interactions }\end{array}$ \\
\hline
\end{tabular}

\section{Genome annotation}

Automated genome annotation was done using the NCBI Prokaryotic Genome Annotation Pipeline [17]. Functional annotations were done by searching against the KEGG [18], InterPro [19], and COG [20] databases. Genes with signal peptides were predicted using SignalP [21]. Genes with transmembrane helices were predicted using TMHMM [22].

\section{Genome properties}

The genome of $K$. oryzae Ola $51^{\mathrm{T}}$ contains one circular chromosome (Fig. 3). The chromosome contains $5,303,342$ nucleotides with $54.0 \% \mathrm{G}+\mathrm{C}$ content. The genome contains 4,926 predicted genes, 4773 proteincoding genes, 105 RNA genes (16 rRNA genes, 76 tRNA genes, and 13 ncRNA genes), 48 pseudo genes, and 1 CRISPR repeats. Among the 4,773 protein-coding genes, 3,765 genes $(78.88 \%)$ have been assigned functions, while 1008 genes $(21.12 \%)$ have been annotated as hypothetical or unknown proteins (Table 3). The distribution of genes into COG functional categories is presented in Table 4 and Fig. 3.

\section{Insights from the genome sequence}

The genome sequences of $K$. cowanii JCM $10956^{\mathrm{T}}$, $K$. radicincitans DSM $16656^{\mathrm{T}}\left(=\mathrm{D} 5 / 23^{\mathrm{T}}\right)$ [23], $K$. radicincitans UMEnt01/12 [24], K. radicincitans YD4 [25], K. sacchari $\mathrm{SP}^{\mathrm{T}}$ [26], "K. pseudosacchari" JM$387^{\mathrm{T}}$ [11], K. oryzae KO348 [27], and Enterobacter sp. R4-368 [28] which was close to $K$. sacchari $\mathrm{SP} 1^{\mathrm{T}}$ [26] had been deposited in the GenBank database. 


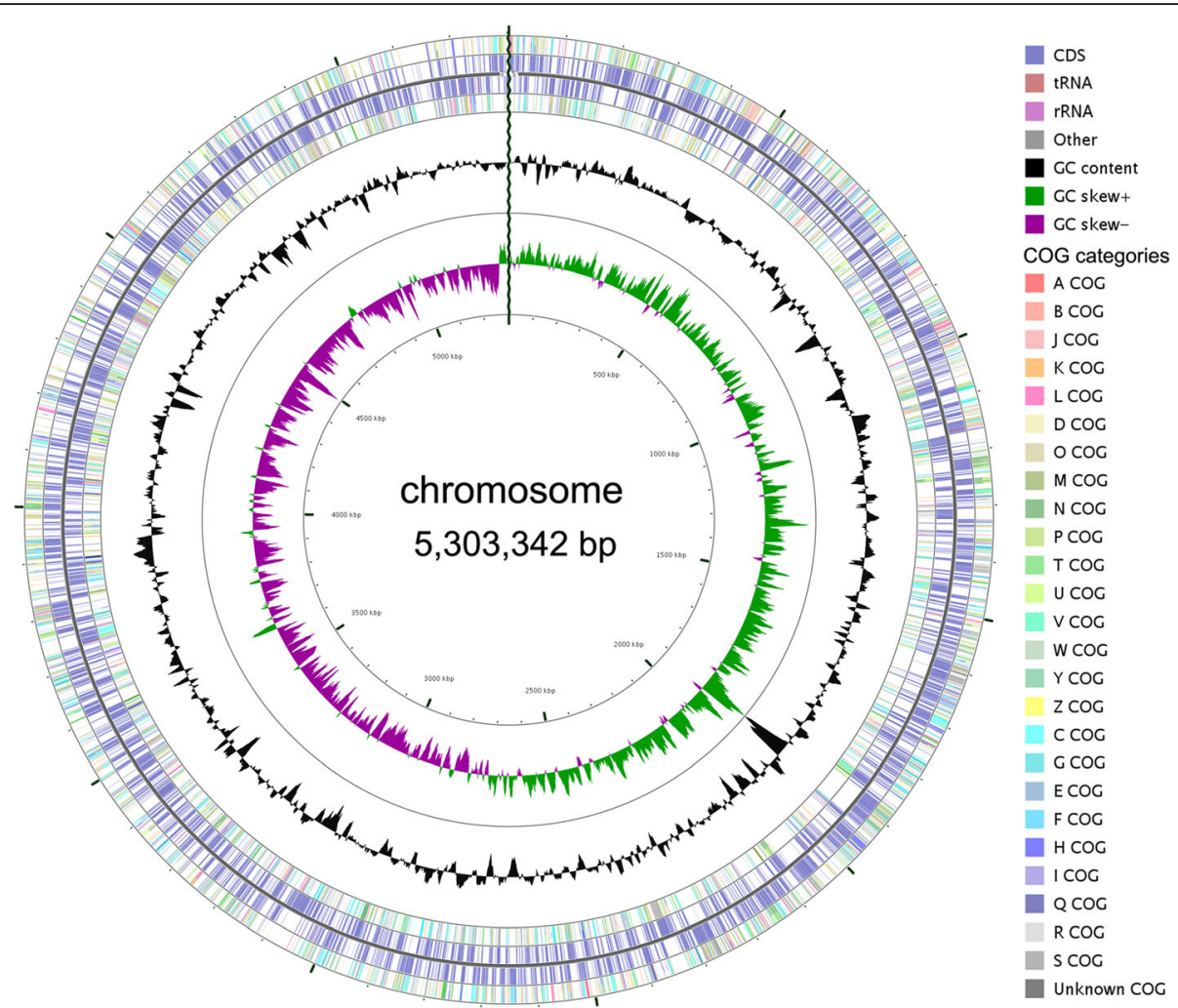

Fig. 3 Circular map of the chromosome of the Kosakonia oryzae strain Ola $51^{\top}$. From outside to the center: CDS on forward strand colored according to their COG categories (oranges/reds: information storage and processing; greens/yellows: cellular processes and signaling; blues/ purples: metabolism; grays: pooly characterized), CDS and RNA genes on forward strand, CDS and RNA genes on reverse strand, CDS on reverse strand colored according to their COG categories, GC content, and GC skew. The circular map was generated by CGView [44]

Table 3 Genome statistics

\begin{tabular}{lll}
\hline Attribute & Value & \% of Total \\
\hline Genome size (bp) & $5,303,342$ & 100 \\
DNA coding (bp) & $4,613,400$ & 86.99 \\
DNA G + C (bp) & $2,864,594$ & 54.01 \\
DNA scaffolds & 1 & 100 \\
Total genes & 4,926 & 100 \\
Protein-coding genes & 4,773 & 96.89 \\
RNA genes & 105 & 2.13 \\
Pseudo genes & 48 & 0.97 \\
Genes in internal clusters & ND & \\
Genes with function prediction & 3765 & 76.43 \\
Genes assigned to COGs & 4237 & 86.01 \\
Genes with Pfam domains & 4416 & 89.65 \\
Genes with signal peptides & 432 & 8.77 \\
Genes with transmembrane helices & 1179 & 23.93 \\
CRISPR repeats & 1 & 0.02 \\
\hline
\end{tabular}

The genome ANIs (Additional file 1: Table S1) between Ola $51^{\mathrm{T}}$ and the other strains belonging to the genus Kosakonia were calculated using the Orthologous Average Nucleotide Identity tool [29]. The cut-off ANI value for species boundary was set at $95 \%-96 \%$ [30]. The ANI value (95.85\%) between $K$. oryzae Ola $51^{\mathrm{T}}$ and $K$. radicincitans DSM $16656^{\mathrm{T}}$ is in the fuzzy zone $95 \%$ - 96\%. The digital DDH value between Ola $51^{\mathrm{T}}$ and DSM $16656^{\mathrm{T}}$ calculated by the Genome-to-Genome Distance Calculator [31] with the Formula 2 is $66.2 \%$, below the $70 \%$ cut-off value for species boundary. Moreover, Ola $51^{\mathrm{T}}$ and DSM $16656^{\mathrm{T}}$ were differentiated by metabolic phenotypes [3, 11] and ribosomal protein mass profiles [5]. Therefore, $K$. oryzae and $K$. radicincitans are closely related sister species.

Strain YD4 was closer to $K$. radicincitans DSM $16656^{\mathrm{T}}$ than $K$. oryzae Ola $51^{\mathrm{T}}$ on the phylogenetic tree based on the 16S rRNA genes (Fig. 2). However, the ANI value and the digital DDH value between YD4 and $K$. radicincitans DSM $16656^{\mathrm{T}}$ is $95.56 \%$ and $64.4 \%$, respectively, while between YD4 and $K$. oryzae Ola $51^{\mathrm{T}}$ is $97.04 \%$ and $74.3 \%$, respectively. Therefore, the strain YD4 belongs to $K$. oryzae but not $K$. radicincitans. 
Table 4 Number of genes associated with general COG functional categories

\begin{tabular}{|c|c|c|c|}
\hline Code & Value & \%age & Description \\
\hline J & 194 & 4.06 & Translation, ribosomal structure and biogenesis \\
\hline A & 1 & 0.02 & RNA processing and modification \\
\hline K & 414 & 8.67 & Transcription \\
\hline L & 140 & 2.93 & Replication, recombination and repair \\
\hline B & 0 & 0 & Chromatin structure and dynamics \\
\hline D & 35 & 0.73 & $\begin{array}{l}\text { Cell cycle control, Cell division, chromosome } \\
\text { partitioning }\end{array}$ \\
\hline V & 60 & 1.26 & Defense mechanisms \\
\hline $\mathrm{T}$ & 278 & 5.82 & Signal transduction mechanisms \\
\hline M & 270 & 5.66 & Cell wall/membrane biogenesis \\
\hline N & 163 & 3.42 & Cell motility \\
\hline U & 123 & 2.58 & Intracellular trafficking and secretion \\
\hline $\mathrm{O}$ & 154 & 3.23 & $\begin{array}{l}\text { Posttranslational modification, protein turnover, } \\
\text { chaperones }\end{array}$ \\
\hline C & 287 & 6.01 & Energy production and conversion \\
\hline G & 428 & 8.97 & Carbohydrate transport and metabolism \\
\hline E & 476 & 9.97 & Amino acid transport and metabolism \\
\hline $\mathrm{F}$ & 93 & 1.95 & Nucleotide transport and metabolism \\
\hline $\mathrm{H}$ & 188 & 3.94 & Coenzyme transport and metabolism \\
\hline । & 152 & 3.18 & Lipid transport and metabolism \\
\hline$P$ & 293 & 6.14 & Inorganic ion transport and metabolism \\
\hline Q & 98 & 2.05 & $\begin{array}{l}\text { Secondary metabolites biosynthesis, transport } \\
\text { and catabolism }\end{array}$ \\
\hline $\mathrm{R}$ & 502 & 10.52 & General function prediction only \\
\hline S & 422 & 8.84 & Function unknown \\
\hline - & 536 & 11.23 & Not in COGs \\
\hline
\end{tabular}

The total is based on the total number of protein coding genes in the genome

Strain KO348 was grouped with $K$. sacchari $\mathrm{SP}^{\mathrm{T}}$, Enterobacter sp. R4-368, and "K. pseudosacchari" JM$387^{\mathrm{T}}$ on the phylogenetic tree based on the $16 \mathrm{~S}$ rRNA genes (Fig. 2). The ANI value between KO348 and $K$. oryzae Ola $51^{\mathrm{T}}$ is $84.04 \%$. The strain $\mathrm{KO} 348$ thus does not belong to $K$. oryzae. The ANI value between KO348 and Enterobacter sp. R4-368 [27], K. sacchari $\mathrm{SP} 1^{\mathrm{T}}$, or " $K$. pseudosacchari" $\mathrm{JM}-387^{\mathrm{T}}$ is $98.80 \%, 94.56 \%$, or $94.05 \%$, respectively. Therefore, KO348 and R4-368 belong to the same species, likely a novel species closely related to $K$. sacchari and " $K$. pseudosacchari".

K. oryzae Ola $51^{\mathrm{T}}$ and YD4, $K$. radicincitans DSM $16656^{\mathrm{T}}$ and UMEnt01/12, K. sacchari SP1 ${ }^{\mathrm{T}}$, "K. pseudosacchari" JM$387^{\mathrm{T}}$, and Kosakonia sp. KO348 and R4-368 were all isolated from plants. Their genomes contain genes encoding multiple enzymes degrading plant cell wall polysaccharides and removing reactive oxygen species, likely facilitating endophytic colonization [32]. They all contain genes encoding the regulatory protein (Fha1) and structural proteins (Lip, IcmF,
DotU and $\mathrm{ClpV}$ ) and secreted proteins (VgrG and Hcp) of the type VI secretion system, which may play a role in the plant-associated lifestyle [32]. Except $K$. radicincitans DSM $16656^{\mathrm{T}}$ and UMEnt01/12, these strains contain the most structural proteins (YscCJRSTUVN) of the type III secretion system, which is not widespread among the previously studied endophytic bacteria [32].

These plant-associated Kosakonia strains contain genes contributing to multiple plant growth-promoting activities. They all contain the nif gene cluster (nifJHDKTYENXUSVWZMFLABQ) for the Mo-Fe nitrogenasedependent nitrogen fixation, the genes encoding indole-3acetaldehyde dehydrogenase, aspartate aminotransferase, aromatic amino acid aminotransferase and phenylpyruvate decarboxylase for producing the phytohormone auxin, and the $b u d A B C$ genes for producing volatile acetoin and 2,3-butanediol which induce plant systemic resistance to pathogens [33]. In addition, $K$. oryzae Ola $51^{\mathrm{T}}$ and YD4, and $K$. radicincitans DSM $16656^{\mathrm{T}}$ and UMEnt $01 / 12$ also contain the anf gene cluster (anfHDGK) for the Fe-Fe nitrogenase-dependent nitrogen fixation. In contrast, the clinical strain $K$. cowanii JCM $10956^{\mathrm{T}}$ does not contain the nif gene cluster.

\section{Conclusions}

The phylogeny of the members of the genus Kosakonia based on the 16S rRNA gene sequences is roughly in agreement with their overall genome relatedness. The complete genome sequence of $K$. oryzae Ola $51^{\mathrm{T}}$ provides the reference genome for genomic identification of strains belonging to $K$. oryzae. Analyses of the overall genome relatedness indices (ANI and digital DDH values), easily and reliably show that $K$. oryzae and $K$. radicincitans are closely related sister species and that the strain YD4, which shows close 16S rRNA gene-based phylogeney to $K$. radicincitans and was classified into $K$. radicincitans, belongs to $K$. oryzae. As well as YD4, which is able to promote growth of the yerba mate plants in low-fertility soils [14], $K$. oryzae Ola $51^{\mathrm{T}}$ contains both the nif gene cluster and the anf gene cluster for nitrogen fixation and genes contributing to production of auxin and volatile acetoin and 2,3-butanediol. Therefore, $K$. oryzae Ola $51^{\mathrm{T}}$ may be able to promote plant growth. Genomic analyses also show that $K$. oryzae Ola $51^{\mathrm{T}}$ and YD4 may have the type III and VI secretion systems and thus motivate us to study the functions of the type III and VI secretion systems in the interactions between beneficial Kosakonia bacteria and plants.

\section{Additional file}

Additional file 1: Table S1. Average nucleotide identities (ANIs) between genomes of the strains belonging to the genus Kosakonia. (DOC $38 \mathrm{~kb}$ ) 


\section{Abbreviations}

ANI: Average nucleotide identity; DDH: DNA-DNA hybridization; SMRT: Single Molecule Real-Time

\section{Funding}

This work was supported by the National Natural Science Foundation of China (31171504, 31370052 and 31471449), Zhejiang Provincial Natural Science Foundation of China (LY14C010002), Science and Technology Planning Project of Guangdong Province (2014A030313459 and 2014A050503058), and the State Key Laboratory of Rice Biology, China.

\section{Authors' contributions}

$Y L, S L$ and $M C$ assembled the sequencing data and completed the genome analysis; GP did the microbiological studies and obtained the organism information; ZT and QA designed the study and wrote the manuscript. All authors read and approved the final manuscript.

\section{Competing interests}

The authors declare that they have no competing interests.

\section{Publisher's Note}

Springer Nature remains neutral with regard to jurisdictional claims in published maps and institutional affiliations.

\section{Author details}

'State Key Laboratory of Rice Biology, Institute of Biotechnology, Zhejiang University, Hangzhou, China. ${ }^{2}$ College of Natural Resources and Environment, South China Agricultural University, Guangzhou 510642, China. ${ }^{3}$ College of Agriculture, South China Agricultural University, Guangzhou 510642, China.

\section{Received: 1 September 2016 Accepted: 7 April 2017}

Published online: 17 April 2017

\section{References}

1. Inoue K, Sugiyama K, Kosako Y, Sakazaki R, Yamai S. Enterobacter cowanii sp. nov., a new species of the family Enterobacteriaceae. Curr Microbiol. 2000;41: 417-20. PubMedhttp://dx.doi.org/10.1007/s002840010160.

2. Kämpfer $P$, Ruppel $S$, Remus R. Enterobacter radicincitans sp. nov., a plant growth promoting species of the family Enterobacteriaceae. Syst Appl Microbiol. 2005;28:213-21. PubMed http://dx.doi.org/10.1016/j.syapm.2004.12.007.

3. Peng G, Zhang W, Luo H, Xie H, Lai W, Tan Z. Enterobacter oryzae sp. nov, a nitrogen-fixing bacterium isolated from the wild rice species Oryza latifolia. Int J Syst Evol Microbiol. 2009;59:1650-5. PubMed http://dx.doi.org/10.1099/ ijs.0.65484-0.

4. Madhaiyan M, Poonguzhali S, Lee J-S, Saravanan VS, Lee K-C, Santhanakrishnan P. Enterobacter arachidis sp. nov., a plant-growthpromoting diazotrophic bacterium isolated from rhizosphere soil of groundnut. Int J Syst Evol Microbiol. 2010;60:1559-64. PubMedhttp://dx.doi. org/10.1099/ijs.0.013664-0.

5. Zhu B, Zhou Q, Lin L, Hu C, Shen P, Yang L, An Q, Xie G, Li Y. Enterobacter sacchari sp. nov., a nitrogen-fixing bacterium associated with sugar cane (Saccharum officinarum L.). Int J Syst Evol Microbiol. 2013;63:2577-82. PubMed http://dx.doi.org/10.1099/ijs.0.045500-0.

6. Hardoim PR, Nazir R, Sessitsch A, Elhottová D, Korenblum E, van Overbeek LS, van Elsas JD. The new species Enterobacter oryziphilus sp. nov. and Enterobacter oryzendophyticus sp. nov. are key inhabitants of the endosphere of rice. BMC Microbiol. 2013;13:164. PubMed http://dx.doi.org/ 10.1186/1471-2180-13-164.

7. Oren A, Garrity GM. Validation list no. 166. Int J Syst Evol Microbiol. 2015:65: 3763-7. PubMed http://dx.doi.org/10.1099/ijsem.0.000632.

8. Brady C, Cleenwerck I, Venter S, Coutinho T, De Vos P. Taxonomic evaluation of the genus Enterobacter based on multilocus sequence analysis (MLSA): proposal to reclassify E. nimipressuralis and E. amnigenus into Lelliottia gen. nov. as Lelliottia nimipressuralis comb. nov. and Lelliottia amnigena comb. nov., respectively, E. gergoviae and E. pyrinus into Pluralibacter gen. nov. as Pluralibacter gergoviae comb. nov. and Pluralibacter pyrinus comb. nov., respectively, E. cowanii, E. radicincitans, E. oryzae and E. arachidis into Kosakonia gen. nov. as Kosakonia cowanii comb. nov. Kosakonia radicincitans comb. nov., Kosakonia oryzae comb. nov. and Kosakonia arachidis comb. nov., respectively, and E. turicensis, E. helveticus and E. pulveris into Cronobacter as Cronobacter zurichensis nom. nov.,
Cronobacter helveticus comb. nov. and Cronobacter pulveris comb. nov., respectively, and emended description of the genera Enterobacter and Cronobacter. Syst Appl Microbiol. 2013;36:309-19. PubMed http://dx.doi.org/ 10.1016/j.syapm.2013.03.005

9. Gu CT, Li CY, Yang LJ, Huo GC. Enterobacter xiangfangensis sp. nov., isolated from Chinese traditional sourdough, and reclassification of Enterobacter sacchari. Int J Syst Evol Microbiol. 2014;64:2650-6. PubMed http://dx.doi.org/ 10.1099/ijs.0.064709-0

10. Li CY, Zhou YL, Ji J, Gu CT. Reclassification of Enterobacter oryziphilus and Enterobacter oryzendophyticus as Kosakonia oryziphila comb. nov. and Kosakonia oryzendophytica comb. nov. Int J Syst Evol Microbiol. 2016. PubMed http://dx.doi.org/10.1099/ijsem.0.001054.

11. Kämpfer P, Mclnroy JA, Doijad S, Chakraborty T, Glaeser SP. Kosakonia pseudosacchari sp. nov., an endophyte of Zea mays. Syst Appl Microbiol. 2016:39:1-7. PubMed http://dx.doi.org/10.1016/j.syapm.2015.09.004.

12. Lin L, Li Z, Hu C, Zhang X, Chang S, Yang L, Li Y, An Q. Plant growthpromoting nitrogen-fixing enterobacteria are in association with sugarcane plants growing in Guangxi. China Microbes Environ. 2012;27:391-8. PubMed http://dx.doi.org/10.1264/jsme2.ME11275.

13. Berger B, Wiesner M, Brock AK, Schreiner M, Ruppel S. K. radicincitans, a beneficial bacteria that promotes radish growth under field conditions. Agron Sustain Dev. 2015;35:1521-8. PubMed http://dx.doi.org/10.1007/s13593-015-0324-z.

14. Bergottini VM, Otegui MB, Sosa DA, Zapata PD, Mulot M, Rebord M, Rebord M, Zopfi J, Wiss F, Benrey B, Junier P. Bio-inoculation of yerba mate seedlings (Ilex paraguariensis St. Hill.) with native plant growth-promoting rhizobacteria: a sustainable alternative to improve crop yield. Biol Fertil Soils. 2015;51:749-55. PubMed http://dx.doi.org/10.1007/s00374-015-1012-5.

15. Field D, Garrity G, Gray T, Morrison N, Selengut J, Sterk P, Tatusova T, Thomson N, Allen MJ, Angiuoli SV, Ashburner M, Axelrod N, Baldauf S, Ballard S, Boore J, Cochrane G, Cole J, Dawyndt P, De Vos P, dePamphilis C, Edwards R, Faruque N, Feldman R, Gilbert J, Gilna P, Glöckner FO, Goldstein P, Guralnick R, Haft D, Hancock D, et al. Minimum Information about a Genome Sequence (MIGS) specification. Nat Biotechnol. 2008;26:541-7. PubMed http://dx.doi.org/10.1038/nbt1360.

16. Eid J, Fehr A, Gray J, Luong K, Lyle J, Otto G, Peluso P, Rank D, Baybayan P, Bettman B, Bibillo A, Bjornson K, Chaudhuri B, Christians F, Cicero R, Clark S, Dalal R, de Winter A, Dixon J, Foquet M, Gaertner A, Hardenbol P, Heiner C, Hester K, Holden D, Kearns G, Kong X, Kuse R, Lacroix Y, Lin S, et al. Realtime DNA sequencing from single polymerase molecules. Science. 2009;323: 133-8. PubMed http://dx.doi.org/10.1126/science.1162986.

17. Tatusova T, DiCuccio M, Badretdin A, Chetvernin V, Nawrocki EP, Zaslavsky L, Lomsadze A, Pruitt KD, Borodovsky M, Ostell J. NCBI prokaryotic genome annotation pipeline. Nucleic Acids Res. 2016;44:6614-24. PubMed http://dx. doi.org/10.1093/nar/gkw569.

18. KEGG [http://www.genome.jp/kegg/]. Accessed 9 Apr 2017.

19. InterPro [http://www.ebi.ac.uk/interpro/scan.html]. Accessed 9 Apr 2017

20. COG [http://weizhong-lab.ucsd.edu/metagenomic-analysis/server/cog/]. Accessed 9 Apr 2017.

21. Bendtsen JD, Nielsen $H$, von Heijne G, Brunak S. Improved prediction of signal peptides: SignalP 3.0. J Mol Biol. 2004;340:783-95. PubMed http://dx. doi.org/10.1016/j.jmb.2004.05.028.

22. Krogh A, Larsson B, von Heijne G, Sonnhammer ELL. Predicting transmembrane protein topology with a hidden Markov model: Application to complete genomes. J Mol Biol. 2001;305:567-80. PubMed http://dx.doi. org/10.1006/jmbi.2000.4315.

23. Witzel K, Gwinn-Giglio M, Nadendla S, Shefchek K, Ruppel S. Genome sequence of Enterobacter radicincitans DSM16656 ${ }^{\top}$, a plant growthpromoting endophyte. J Bacteriol. 2012;194:5469. PubMed http://dx.doi.org/ 10.1128/JB.01193-12.

24. Mohd Suhaimi NS, Yap KP, Ajam N, Thong KL. Genome sequence of Kosakonia radicincitans UMEnt01/12, a bacterium associated with bacterial wilt diseased banana plant. FEMS Microbiol Lett. 2014;358:11-3. PubMed http://dx.doi.org/10.1111/1574-6968.12537

25. Bergottini VM, Filippidou S, Junier T, Johnson S, Chain PS, Otegui MB, Zapata PD, Junier P. Genome sequence of Kosakonia radicincitans strain YD4, a plant growth-promoting rhizobacterium isolated from yerba mate (Ilex paraguariensis St. Hill.). Genome Announc. 2015;3:e00239-15. PubMed http://dx.doi.org/10.1128/genomeA.00239-15.

26. Chen M, Zhu B, Lin L, Yang L, Li Y, An Q. Complete genome sequence of Kosakonia sacchari type strain SP1 ${ }^{\top}$. Stand Genomic Sci. 2014;9:1311-8. PubMed http://dx.doi.org/10.4056/sigs.5779977. 
27. Meng X, Bertani I, Abbruscato P, Piffanelli P, Licastro D, Wang C, Venturi V. Draft genome sequence of rice endophyte-associated isolate Kosakonia oryzae KO348. Genome Announc. 2015;3:e00594-15. PubMed http://dx.doi. org/10.1128/genomeA.00594-15.

28. Madhaiyan M, Peng N, Ji L. Complete genome sequence of Enterobacter sp. strain R4-368, an endophytic N-fixing gammaproteobacterium isolated from surface-sterilized roots of Jatropha curcas L. Genome Announc. 2013;1: e00544-13. PubMed http://dx.doi.org/10.1128/genomeA.00544-13.

29. Lee I, Kim YO, Park S-C, Chun J. OrthoANI: An improved algorithm and software for calculating average nucleotide identity. Int I Syst Evol Microbiol. 2016;66:1100-3. PubMed http://dx.doi.org/10.1099/ijsem.0.000760

30. Richter M, Rosselló-Móra R. Shifting the genomic gold standard for the prokaryotic species definition. Proc Natl Acad Sci U S A. 2009;45:19126-31. PubMed http://dx.doi.org/10.1073/pnas.0906412106.

31. GGDC [http://ggdc.dsmz.de/distcalc2.php]. Accessed 9 Apr 2017.

32. Reinhold-Hurek B, Hurek T. Living inside plants: bacterial endophytes. Curr Opin Plant Biol. 2011;14:435-43. PubMed http://dx.doi.org/10.1016/j.pbi. 2011.04.004.

33. Ryu CM, Farag MA, Hu CH, Reddy MS, Wei HX, Paré PW, Kloepper JW. Bacterial volatiles promote growth in Arabidopsis. Proc Natl Acad Sci U S A. 2003;100:4927-32. PubMed http://dx.doi.org/10.1073/pnas.0730845100.

34. Woese $\mathrm{CR}$, Kandler $\mathrm{O}$, Wheelis ML. Towards a natural system of organisms: proposal for the domains Archaea, Bacteria, and Eucarya. Proc Natl Acad Sci U S A. 1990;87:4576-9. PubMed http://dx.doi.org/10.1073/pnas.87.12.4576.

35. Garrity GM, Bell JA, Lilburn T. Phylum XIV. Proteobacteria phyl. nov. In: Garrity GM, Brenner DJ, Krieg NR, Staley JT, editors. Bergey's Manual of Systematic Bacteriology, Volume 2, Part B. 2nd ed. New York: Springer; 2005. p. 1.

36. Garrity GM, Bell JA, Lilburn T. Class III. Gammaproteobacteria class. nov. In: Garrity GM, Brenner DJ, Krieg NR, Staley JT, editors. Bergey's Manual of Systematic Bacteriology, Volume 2, Part B. 2nd ed. Springer: New York; 2005. p. 1.

37. Validation of publication of new names and new combinations previously effectively published outside the IJSEM. List no. 106. Int J Syst Evol Microbiol.2005;55:2235-8. PubMed http://dx.doi.org/10.1099/ijs.0.64108-0.

38. Garrity GM, Holt JG. Taxonomic Outline of the Archaea and Bacteria. In: Garrity GM, Boone DR, Castenholz RW, editors. Bergey's Manual of Systematic Bacteriology, Volume 1. 2nd ed. New York: Springer; 2001. p. 155-66.

39. Rahn O. New principles for the classification of bacteria. Zentralblatt für Bakteriologie, Parasitenkunde, Infektionskrankheiten und Hygiene. Abteilung II. 1937:96:273-86.

40. Skerman VBD, McGowan V, Sneath PHA. Approved Lists of Bacterial Names. Int J Syst Bacteriol. 1980;30:225-420. PubMed http://dx.doi.org/10.1099/ 00207713-30-1-225.

41. Ashburner M, Ball CA, Blake JA, Botstein D, Butler $H$, Cherry JM, Davis AP, Dolinski K, Dwight SS, Eppig JT, Harris MA, Hill DP, Issel-Tarver L, Kasarskis A, Lewis S, Matese JC, Richardson JE, Ringwald M, Rubin GM, Sherlock G. Gene ontology: tool for the unification of biology. Nat Genet. 2000;25:25-9. PubMed http://dx.doi.org/10.1038/75556.

42. SINA Alignment Service [https:/www.arb-silva.de/aligner/]. Accessed 9 Apr 2017.

43. Tamura K, Peterson D, Peterson N, Stecher G, Nei M, Kumar S. MEGA5: molecular evolutionary genetics analysis using maximum likelihood, evolutionary distance, and maximum parsimony methods. Mol Biol Evol. 2011;28:2731-9. PubMed http://dx.doi.org/10.1093/molbev/msr121.

44. Stothard $\mathrm{P}$, Wishart DS. Circular genome visualization and exploration using CGView. Bioinformatics. 2005;21:537-9. PubMed http://dx.doi.org/10.1093/ bioinformatics/bti054.

\section{Submit your next manuscript to BioMed Central and we will help you at every step:}

- We accept pre-submission inquiries

- Our selector tool helps you to find the most relevant journal

- We provide round the clock customer support

- Convenient online submission

- Thorough peer review

- Inclusion in PubMed and all major indexing services

- Maximum visibility for your research

Submit your manuscript at www.biomedcentral.com/submit
Biomed Central 